\title{
The Protection of Indonesian Migrant Workers under Fiqh Siyasah Dusturiyah
}

\section{Habib Ismail}

\section{LAIMNU Metro Lampung, Indonesia}

\section{Dani Amran Hakim}

UIN Raden Intan Lampung, Indonesia

\section{Muhammad Lutfi Hakim \\ IAIN Pontianak, Indonesia}

\begin{abstract}
The position of migrant workers is often seen as a weak party. To some extent, such migrant workers are regarded as similar to slaves. In Indonesia, the government has to protect all citizens, including those abroad who have the status of migrant workers. Migrant Workers' Protection Law 18/2017 was issued to protect citizens as migrant workers. However, several migrant workers remained legally unprotected abroad. This study used the normative approach that aimed to discuss the protection of Indonesian migrant workers from two-fold, juridical and fiqh siyasah dusturiyah perspectives. While the government protected migrant workers by issuing Law 18/2017, it has more specifically provided directions and objectives to protect migrant workers. This Law ensures human rights for migrant workers despite legal, economic, and social protection for them and their families. Then, the protection of migrant workers from fiqh siyasah dusturiyah should be under the four principles of the workforce in Islam: human independence, human dignity, justice, and the clarity of the contract and wage transaction.
\end{abstract}

KEYWORDS: Indonesian Migrant Workers, Right to Work, Islamic Law.

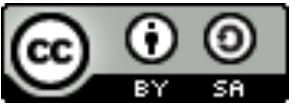

Copyright (C) 2021 by Author(s)

This work is licensed under a Creative Commons Attribution-ShareAlike 4.0 International License. All writings published in this journal are personal views of the authors and do not represent the views of this journal and the author's affiliated institutions.

\section{HOW TO CITE:}

Ismail, Habib, et al., "The Protection of Indonesian Migrant Workers under Figh Siyasah Dusturiyah" (2021) 8:1 Lentera Hukum 151-174. DOI: <https://doi.org/10.19184/ejlh.v8i1. 18725>.

Submitted: 22/12/2020 Reviewed: 28/12/2020 Revised: 05/03/2021 Accepted: 12/03/2021

\footnotetext{
*Corresponding author's e-mail: habibismail65@gmail.com
} 


\section{INTRODUCTION}

Connie de la Vega, Professor of Law at the University of San Francisco, experienced researching immigrant worker issues since 1976. He defined a migrant worker as a person who will, is currently, or has been doing wage work other than his home country. ${ }^{1}$ It strongly relates to the definition in the Indonesian Migrant Workers' Protection Law 18/2017. It states that migrant workers are citizens who will, are currently, or work with wages outside the Indonesian territory. Migrant workers play an essential role in economic growth in many developing countries with huge populations like Indonesia and the Philippines. ${ }^{2}$ It refers to the economic contribution of the home state and the host state. Consequently, the government is obliged to guarantee migrant workers' protection in the country where they work. In Indonesia, such responsibility is reflected in Article 27(2) of the 1945 Constitution; it extends the right to work and a decent living as part of the constitutional rights. The limitations of domestic employment have resulted in many citizens seeking work abroad to become migrant workers. ${ }^{3}$ However, it has not been well implemented. Among the factors that cause many Indonesian citizens to become immigrant workers is the limited job opportunities available in the country, forcing many Indonesian citizens to become migrant workers abroad to survive their families. The last ten years' data showed the unemployment rate was dominated by graduates of the High School and Vocational Schools. ${ }^{4}$

This high unemployment affirms the government's inadequate fulfillment in employment opportunities. The lack of domestic employment and the

1 Connie De La Vega \& Conchita Lozano-Batista, "21 Advocates Should Use Applicable International Standards to Address Violations of Undocumented Migrant Workers' Rights in the United States" in Anne F Bayefsky, Human Rights and Refugees, Internally Displaced Persons and Migrant Workers (Martinus Nijhoff Publishers, 2006) 517 at 517.

2 AKM Ahsan Ullah \& Sharifah Nurul Huda Alkaff, "Biological Remittance Among Migrant Workers: Social Ramifications in the Philippines and Indonesia" (2018) 53:6 Journal of Asian and African Studies 896-916.

3 BP2MI, "Data Penempatan dan Perlindungan TKI Periode Tabun 2019" (2020) online: <https://bp2mi.go.id/uploads/statistik/images/data_21-10-2020_Laporan_ Pengolahan_Data_BNP2TKI_agustus_2020_(1).pdf $>$.

4 BPS, Data Survei Angkatan Kerja Nasional (Badan Pusat Statistik Indonesia, 2017). 
high rate of educated unemployment causes the unemployed workforce with education up to the High School level to reconsider competing for jobs. Then, this situation becomes the driving factor resulting in increasing migrant workers. The National Agency for the Placement and Protection of Indonesian Workers (BNP2TKI) recorded 148,285 migrant workers move to destination countries during January-August 2017.5 Job opportunities and high income were the main attractions for Indonesian migrants to work abroad. ${ }^{6}$ However, many migrant workers could not obtain adequate legal protection from the government. This Agency released the number of complaints in January-March 2019 based on 1,759 problems. ${ }^{7}$ The issues were unpaid wages, overstay, and non-conformance work to the agreement. ${ }^{8}$ As such issues have flourished, criminal issues became another concern faced by them. In 2011-2018, Saudi Arabia authorities executed five migrant workers. ${ }^{9}$ The execution of two migrant workers was made without prior notification to the Indonesian government. ${ }^{10}$ In addition, 23 others were under the death sentence in Saudi Arabia. ${ }^{11}$ Thus, the government's responsive role is undeniable to protect them and prevent other similar cases.

The government's obligation to protect citizens has received significant attention in fiqh siyasah dusturiyah. In this context, fiqh siyasah dusturiyah discusses legal issues, both the legislation and the rule of law in Islamic

5 Aga Natalis \& Budi Ispriyarso, "Politik Hukum Perlindungan Pekerja Migran Perempuan di Indonesia" (2018) 13:2 Pandecta Research Law Journal 109-123 at 109.

6 Hamdan Tri Atmaja, "Model Pemberdayaan Keluarga Tenaga Kerja Wanita (TKW) Indonesia Berbasis Arena Produksi Kultural dalam Upaya Menciptakan Keluarga Mandiri Sejabtera di Propinsi Jawa Timur" (2014) 41:1 Forum Ilmu Sosial, Fakultas Ilmu Sosial Universitas Negeri Semarang at 26. See also: Tri Lisiani Prihatinah, et al., "Kendala Perlindungan Hukum Terbadap Buruh Migrandi Kabupaten Cilacap," (2012) 12:2 Jurnal Dinamika Hukum.

7 BNP2TKI, "Data Penempatan dan Perlindungan TKI Periode 1 Januari-31 Maret 2019" (2019), online: <http://portal.bnp2tki.go.id/uploads/data/data_18-04-2019_ 010851_Laporan_Pengolahan_Data_BNP2TKI_Bulan_Maret_.pdf>.

8 Ibid.

9 Eprida Sani \& Shary Charlotte Henriette Pattipeilohy, "Analisis Pengaruh Hukuman Mati Pekerja Migran Indonesia terhadap Hubungan Bilateral Indonesia dan Arab Saudi 2010-2018" (2020) 6:2 Journal of International Relations 238-247 at 241.

10 Ibid.

${ }^{11}$ Ibid. 
politics, with the reciprocal relationship between the government and citizens and the rights of citizens obliged to be protected. ${ }^{12}$ Through this lens, the government must protect all citizens, including those living abroad like migrant workers, with sufficient legal protection and assistance. This paper focuses on Indonesian migrant workers' protection based on the existing law and its compliance with migrant workers' demands that require protection abroad from fiqh siyasah dusturiyah.

Several pieces of research reviewed the protection for Indonesian migrant workers. Natalis and Ispriyarso discussed the protection of female migrant workers. ${ }^{13}$ They noted that the protection had not included female migrant workers to regulate women in a special position. In addition, Widiyahseno suggested adopting a new paradigm of protecting the migrant. ${ }^{14}$ It was not sure that it could significantly impact migrant workers because there were no government regulations and regional regulations. In contrast, Bareta and Ispriyarso discussed migrant workers' protection in the post-work phase. ${ }^{15}$ They argued that the legal and political instrument for protecting migrant workers needs to be improved so that the government's target of unavailable domestic workers can be achieved. Hardani and Rahayu focused on researching non-derogable rights protection for undocumented migrant workers. ${ }^{16}$ They concluded that the government had not provided legal protection for undocumented Indonesian migrant workers because the existing laws in Indonesia prioritize the prevention model. Meanwhile,

12 Muhammad Iqbal, Fiqh Siyasah: Kontekstualisasi Doktrin Politik Islam (Jakarta: Gaya Media Pratama, 2001) at 177.

13 Aga Natalis \& Budi Ispriyarso, "Politik Hukum Perlindungan Pekerja Migran Perempuan di Indonesia" (2018) 13:2 Pandecta Research Law Journal 109-123 at 109.

14 Bambang Widiyahseno, "Paradigma Baru Model Pelindungan Pekerja Migran Indonesia dalam Perspektif Undang-Undang RI Nomor 18 Tahun 2017” (2017) 4:3 Sosio Informa 501-513 at 501.

15 Rizky Dian Bareta \& Budi Ispriyarso, "Politik Hukum Perlindungan Tenaga Kerja Indonesia Fase Purna Bekerja" (2018) 20:1 Kanun Jurnal Ilmu Hukum 163-182 at 163.

16 Ayuk Hardani \& Rahayu, "Politik Hukum Perlindungan Non-Derogable Rights Pekerja Migran Indonesia Tidak Berdokumen” (2019) 3:2 Refleksi Hukum: Jurnal Ilmu Hukum $115-128$ at 115. 
Anggriani focused on irregular migrant workers in Southeast Asia. ${ }^{17}$ She argued that irregular migrant workers' position is similar to other Indonesian migrant workers. ${ }^{18}$ Therefore, the government should protect them under international human rights law.

From a piece of literature as mentioned above, none of them use the fiqh siyasah dusturiyah review in analyzing the protection of the Indonesian migrant workers. They were limited to explore the protection of migrant workers from a juridical perspective. Some of them focused on the protection in the post-employment phase and protection of non-derogable rights were undocumented and irregular migrant workers in Southeast Asia from international human rights law. The absence of fiqh siyasah dusturiyah review increasingly adds a debate in examining the government's role in providing human rights protection.

This paper aimed to discuss the protection of Indonesian migrant workers from two-fold, juridical and figh siyasah dusturiyah perspectives. Thus, it has two parts of the discussion. The first part overviews the legal protection of the Indonesian migrant workers that covers the development of regulations and legal protection before, during, and after the work, including strengthening the government role. The second part examines and analyzes the protection from the perspective of fiqh siyasah dusturiyah.

\section{METHODS}

This study used a normative approach under juridical and fiqh siyasah dusturiyah perspectives. This approach refers to legal literature by examining theories, concepts, law principles, and legislation on migrant workers. It used secondary data obtained from research results, articles, and reference books with related topics that focus on research problems. The specification of this research is descriptive analytics, which includes the scope of research by describing, examining, and explaining precisely and

17 Riri Anggriani, "Perlindungan Hukum bagi Irregular Migrant Workers Indonesia di Kawasan Asia Tenggara (Dalam Perspektif Hukum HAM Internasional)” (2017) 32:2 Yuridika $310-335$ at 310.

18 Ibid. 
analyzing the legal politics of legislation on the protection of migrant workers and analyzed under fiqh siyasah dusturiyah.

\section{PROTECTING INDONESIAN MIGRANT WORKERS}

\section{A. The Development of Protection Law for Migrant Workers}

Before enacting the existing law, on October 18, 2004, the Indonesian government passed a law aimed to protect the rights of migrant workers through the Placement and Protection of Indonesian Workers Abroad Law 39/2004. The protection is also intended that the government can provide good policies to Indonesian migrant workers. However, after enacting Law $39 / 2004$, there was resistance from various societal levels, and it never went out. This rejection showed that some people do not trust the government in protecting migrant workers. Public trust in the government in responding to Law 39/2004 is crucial to facilitate various policies. ${ }^{19}$ Therefore, it is necessary to change the rules of migrant workers' protection in force. Consequently, in enacting a statutory regulation, the government must accommodate the aspirations and needs of citizens.

The most vigorous rejection and resistance came from non-governmental organizations (NGOs). They considered that the government policy in Law 39/2004 views migrant workers as nothing more than a commodity. ${ }^{20}$ Implementing government policies still contains a spirit of discrimination. For example, even policies for the placement of migrant workers have led to human trafficking policies. ${ }^{21}$ With the rampant rejection and negative response to the Law 39/2004, then on April 12, 2012, the House of

19 Ambar Widaningrum, "Public Trust and Regulatory Compliance" (2017) 21:1 Jurnal Ilmu Sosial dan Ilmu Politik 1 at 11.

20 Era Moslem, "Pemerintah Hanya Jadikan TKI Sebagai Komoditas" (2020) online: <http://www.eramoslem.com/br/fo/48/12377,1v.html>.

${ }^{21}$ Tempo, "Komnas HAM, "Hak Asasi Burub Migran Indonesia," (2004) online: $<$ https://www.tempointeraktif.com/hg/narasi/2004/06/17/nrs,20040617-07,id>.

html>. See: Tempo, "Depnakertrans Bantab RUU Perlindungan TKI Mengukubkan Trafficking” (2004) online: <https:/www.tempointeraktif.com/hg/nasional/2004/ 09/17/brk,20040917-31,id.html>. See also: Indonesian Ministry of Law and Human Rights, "Laporan Akbir Analisis dan Evaluasi Hukum Mengenai Perlindungan Hak dan Keselamatan Pekerja Migran" (Ministry of Law and Human Rights, 2016). 
Representatives passed a law regarding the ratification of the International Convention on the Protection of the Rights of All Migrant Workers and Members of their Families through Law 6/2012 (the Migrant Workers Convention 1990). Based on this law, the protection for migrant workers and their families is regulated more specifically than that in Law 39/2004. ${ }^{22}$ Finally, in October 2017, the Government and the House ratified the Bill on the Protection of Indonesian Migrant Workers into Law 18/2017, replacing the Law 39/2004. It marked the end of the long, slow, and steep journey of the legislative process to protect Indonesian migrant workers who face the vulnerability of human rights violations at any time, from wages, expulsion, abuse, sexual harassment, rape, and even the death penalty.

Article 3 of Law 18/2017 provides directions for the objectives to be achieved in migrant protection, to ensure (a) the fulfillment and enforcement of the rights of migrant workers and (b) the legal, economic, and social protection for them and their families. According to Law $18 / 2017$, human rights protection includes the migrant workers' protection from human trafficking, slavery and forced labor, victims of violence, abuse, crimes against human dignity, and other acts that violate human rights.

The essential points in Law 18/2017 cover migrant workers for legal employers, migrant workers for individual employers, and seafarers and fishery seafarers. It also deals with the rights and obligations of migrant workers and their families. It includes protection in the placement system (before, during, and after the work). In addition, it concerns labor attachés, one-stop integrated services, financing systems in favor of candidates or migrant workers, administering migrant workers' social security, and legal, social, and economic protection. It is important to note that Law 18/2017 regulates the central government and local governments' duties and responsibilities. Article 1:5 of Law 18/2017 stipulates the protection of migrant workers to protect the interests of candidates and migrant workers and their families for the fulfillment of rights before, during, and after the work in legal, economic, and social aspects.

22 Bareta \& Ispriyarso, supra note 3 at 172. 


\section{B. Protecting Migrant Workers: Before, During, and After the Work}

Law 18/2017 regulates the protection more systematically and comprehensively in a separate chapter. This Law consists of 20 protection rules before, during, and after the work and several regulations related to legal, economic, and social protection as many as six articles. For example, regulation of protection of Indonesian migrant workers before the work based on Article 8 includes two aspects, administrative and technical. Administrative protection includes the completeness and validity of placement documents and the determination of working conditions such as marriage certificates, family permits, health certificates, work competency certificates, passports, work visas, placement agreements, and work agreements. In addition, the process under Article 12(2) of Law 18/2017 will be further regulated in the regulation of the head of the Agency. The protection of technical aspects includes information dissemination, education, training, facilities for the fulfillment of rights, services in integrated services one roof (LTSA), social security, strengthening operational staff, and guidance and supervision.

Article 15 of Law 18/2017 regulates business partners' verification (recruitment agencies) abroad and service users. The labor attaché is also obliged to make and publish a list of business partners and service users who have problems periodically based on this verification. The verification results will be used as material for recommendations in granting placement permits for Indonesian migrant workers forging companies (PPPMI) partnering with business partners on the blocklisting. Article 19(2) of Law $18 / 2017$ regulates the protection section before employment regulates the work agreement contents, the work agreement's term, the procedure for extension of the work agreement, and administrative sanctions for PPPMI. They do not place the candidates of Indonesian migrant workers according to those stated in the work agreement.

The rules regarding protection after the work, Law 18/2017 facilities for returning to the area of origin, settlement of rights, facilities for managing workers' illness/death, rehabilitation and social reintegration, and 
empowerment for workers and their families. The rest of this section regulates the obligation to report data on workers' arrival and return. ${ }^{23}$

\section{Strengthening the Government's Role}

Based on the previous regulation, Law 39/2004, the role of the private sector was considered very dominant at all stages of migration, starting from providing information, collecting data, processing documents, organizing education, pre-departure, shelter, medical check-up, the process of departure, solving problems and taking care of their return. It becomes one of the main factors that cause migrant workers and their families vulnerable to human rights violations and ensnare them into complicated matters.

Through Law 18/2017, the government has strong legitimacy to guarantee, protect, and fulfill the rights of migrant workers and their families by reducing the role of the private sector in their placement and protection. In this law, labor migration governance, previously centralized, became decentralized with local governments' involvement from Provinces to Villages. Strengthening government role at both the central and regional levels shows the government's commitment to protect and respect human rights. It also determines that the duties and responsibilities of PPPMI in Law 18/2017 are to seek job opportunities, locate and solve problems. It regulates the duties and authorities of the central and regional governments and the roles and functions of the Agency as executing policies of protecting migrant workers. Then, the National Agency for the Placement and Protection of Indonesian Workers (BNP2TKI) was also established under Law 39/2004, strengthening its function and role as executor of protection to Indonesian migrant workers. The implementation of protecting migrant workers required strict supervision and law enforcement. The supervision included protection before, during, and after the work.

23 Savitri Wisnuwardhani, Memahami Undang-Undang Perlindungan Pekerja Migran Indonesia :Kelebihan dan Kelemahan UU PPMI (Jakarta: Jaringan Buruh Migran: The Institute for Ecosoc Rights, 2018) at 2-3. 


\section{THE PROTECTION OF MIGRANT WORKERS UNDER FIQH SIYASAH DUSTURIYAH}

Azyumardi Azra argues that Indonesia has experienced a transition from authoritarianism to democracy since $1998,{ }^{24}$ under auspices of the reformation. ${ }^{25}$ After two decades of the reformation, Islam as the religion of most of the population continues to experience a resurgence. ${ }^{26}$ Simultaneously, which began in the second half of the 1980s, democracy has reached a point of no return; religion is seen to be increasingly prominent in the public sphere. ${ }^{27}$ It is exemplified with the continued widespread use of the hijab, the increased number of Haj and Umrah pilgrims, and its increase in Islamic banking. ${ }^{28}$ This resurgence also leverages the government in making regulations that are, of course, in harmony with it.

These developments certainly affect the development of law in Indonesia. Increased awareness in the state and society using Islamic principles affects the formation of statutory regulation. In Islam, the purpose of making legislation is to realize the benefit and to meet human needs. It is in line with siyasab dusturiyah that discusses the regulations and legislation required by matters of the state regarding conformity with religious principles and the realization of human benefit and fulfilling human needs. ${ }^{29}$ The concept of siyasah dusturiyah is part of fiqh siyasah. Then, it examines how Islam's influence is the fiqh siyasab dusturiyah perspective on Law 18/2017.

${ }^{24}$ In Islamic law, authoritarianism is an attitude that considers his opinion or the results of his ijtihad the most correct, final, undeniable, and others are considered wrong. Muhammad Lutfi Hakim, "Hermeneutik-Negosiasi dalam Studi Fatwa-Fatwa Keagamaan: Analisis Kritik terhadap Pemikiran Khaled M. Abou El Fadl" (2020) 19:1 Istinbath $27-52$ at 35.

25 Muhammad Bahrul Ulum, "Indonesian Democracy and Political Parties After Twenty Years of Reformation: A Contextual Analysis" (2020) 10:1 Indones Law Review.

26 Muhammad Lutfi Hakim, supra note 24 at 35.

27 Ibid.

28 Azyumardi Azra, "Kesalehan dan Politik: Islam Indonesia" (2018) 25:3 Studia Islamika $639-650$ at 645.

29 H.A. Djazuli, Figh Siyasah Implementasi Kemaslahatan Umat dalam Rambu-Rambu Syari"ab (Jakarta: Kencana, 2003) at 47. 
In discussing fiqh siyasah dusturiyah, it is essential to define each word. The word "siyasah" comes from "sasa" which has several meanings. They are regulating, managing, ruling, leading, making policy, government, and politics. ${ }^{30}$ Siyasab in Arabic speech is to organize or lead something by bringing it to benefit (maslahab). ${ }^{31}$ This linguistic understanding implies that siyasah aims to organize, manage, and make policy on something political to cover something in the public interest.

The word figh comes from faqaba-yafqabu-fiqhan. In language, the meaning of $f i q h$ is a deep understanding. ${ }^{32}$ Etymologically, fiqh is a description of the meaning or deep understanding of words and actions' meanings. ${ }^{33}$ It asserts that fiqh is a serious effort by the ulama (mujtabidin) to explore syara' laws to be practiced by Muslims. The understanding of Islamic law has undergone changes and developments according to the human condition and situation.

While the two words fiqh and siyasah are combined, the terms have various meanings. First, according to Imam al-Bujairimi, fiqh siyasah attempts to improve or improve people's problems and regulate them by ruling them for them because of their obedience to the government. ${ }^{34}$ Second, according to Wuzârat al-Awqaf wa al-Syu'un al-Islâmiyyah bi al-Kuwait, fiqh siyasah is an effort to improve human life by showing them the path that can save them in the present and future and manage their problems. ${ }^{35}$ Third, according to Imam Ibn Abidin, figh siyasab is the benefit of humankind, showing it to the path that saves humans on their life and the hereafter. ${ }^{36}$

30 Ibn Manzhur, Lisan al-Arab (Beirut: Dar al-Shadr, 1968) at 108.

31 Ali Akhbar Abaib Mas Rabbani Lubis, "Open Promotion Sekda Kabupaten Sambas: Perspektif Fikih Siyasah dan Perundang-Undangan di Indonesia" (2020) 1:2 Journal of Islamic Law 158-181 at 169.

32 Iqbal, supra note 30 at 2.

33 J Suyuthi Pulungan, Fiqh Siyasah: Ajaran, Sejarah dan Pemikiran (Jakarta: RajaGrafindo Persada, 1999) at 21.

34 Djazuli, supra note 29 at 2.

35 Ali Syariati, Imamah dan Umamah, translated by Afif Muhammad (Mizan, 1989) at 44.

${ }^{36}$ Ibid at 46. 
At first glance, fiqh siyasah and politics look almost the same. This equation can be seen from the two elements in both, namely the party that regulates and the regulated party. These two elements are essential and reciprocal elements, both in figh siyasah and in political science. It is similar because there are two important elements in the political field: the state whose orders are exclusive and the elements of society, which are regulated or governed. Thus, fiqh siyasah is one aspect of Islamic law in a state that benefits humans. In fiqh siyasah, mujtahid scholars explore Islamic law sources regarding the relationship with state life. ${ }^{37}$ In this context, the holders of power are obliged to make regulations and policies to regulate the state and community to achieve prosperity based on the Qur'an and Hadith guidelines. Thus, figh siyasah studies precisely all matters and intricacies of state and government governance.

According to Imam al-Mawardidi in his book entitled al-Ahkam alShultaniyyah, the scope of the study of figh siyasab includes policies regarding siyasabdusturiyah (statutory regulations), siyasah mäliyyah (economic and monetary), siyasahqadhä'iyyah (law of war), siyasah harbiyah (law of war), siyasabiddariyyah (state administration) and siyasah dauliyah (international relations). ${ }^{38}$ According to Muhammad Iqbal, the division of fiqh siyasah can be simplified into three main parts. First, political legislation (siyasab dusturiyah), second, foreign policy (siyasah dauliyyah), third, financial and monetary politics (siyasah māliyyah). ${ }^{39}$ Therefore, the principles of Islam in the state administration are very broad in scope. The formulation of the law relates to the duties of the legislative bodies discussed in siyasah dusturiyah.

The word "dusturiyab" comes from the Persian word, which means dusturi. ${ }^{40}$ Initially, it meant a person who had authority, both in politics and

37 Iqbal supra note 12 at 140 .

38 Ibn Taimiyah, Siyasah al-Syar'iyah fi Ishlah al-Ra'I wa al-Ra'iyah (Egypt: Dar alKitab al-Arabi).

39 Iqbal, supra note 30 at $15-16$.

40 Sri Kantun, "Uji Materiil Undang-Undang PeradilanAgama dalam Prespektif Fikih Siyasah,” (2016) 19:2 Al-Qanun: Jurnal Pemikiran dan Pembaharuan Hukum Islam at 147. 
religion. ${ }^{41}$ After experiencing absorption into Arabic, the word "dusturiyah" develops its meaning into a fundamental principle. Siyasah dusturiyah is a part of fiqh siyasah that discusses the issue of state legislation. ${ }^{42}$ The discussion includes, among other things, constitutional concepts (the country's constitution and the history of the birth of laws in a country), legislation (how to formulate laws), democratic institutions, and shura, which are essential pillars in these laws. This study discusses the rule of law in siyasah and the reciprocal relationship between the government and citizens, including citizen rights obliged to be protected by the government. ${ }^{43}$

The figh siyasah dusturiyah is a part of figh siyasah, which regulates the relationship between citizens and one state institution and citizens of the state and other state institutions within the administrative boundaries. In society, the scope of discussion is vast. Therefore, in figh siyasah dusturiyah, it is usually limited to discussing regulations and legislation (legislation) required by state matters regarding conformity with religious principles, which realize humankind's benefit fulfills their needs.

The study of figh siyasab regarding legislation or legislative power is also called al-sulthāh al-tasyri'iyah. ${ }^{44} \mathrm{It}$ is the power of the Islamic government in making and enacting laws. In this context, the legislative power determines the law to be enforced and implemented by the community based on the provisions revealed by Allah (God) in Islamic law. Thus, in al-sulthāh al-tasyri'iyah, the government forms laws enforced in Islamic society for Muslims' benefit under Islamic teachings. ${ }^{45}$

The connection is to study a state law in the form of statutory regulations, studied in terms of legal politics regarding Indonesian migrant workers' protection must be clear and precise in the rules. Law 18/2017 is further studied based on the figh siyasah dusturiyah perspective regarding its

${ }^{41}$ Muhakki Muhakki, "Mekanisme Suara Terbanyak Bagi Pemilu Legislatif(Studi Siyasah Dusturiyah)" (2011) 1:2 Al Daulah: Jurnal Hukum dan Perundangan Islam 135-158 at 135.

42 J Suyuthi Pulungan, supra note 33 at 40-41.

43 Iqbal, supra note 30 at 177.

44 Ibid at 162.

45 Ibid at 188. 
implementation. Its foundations are also sought through the sources of Islamic law.

\section{A. Sources of Figh Siyasab Dusturiyah}

Each discipline has sources in study. From these sources, such discipline develops according to the demands and challenges of the times. Likewise, with fiqh siyasah dusturiyah. As a branch of fiqh science, fiqh siyasah dusturiyah has referenced sources. In general, the sources of figh siyasab dusturiyah can be divided into primary and secondary sources. Fathiyah alNabrawi divides the sources of figh siyasah dusturiyah into three parts. ${ }^{46}$ They are the Qur'an and Sunnah, written sources other than the Qur'an and Sunnah, and sources in the form of the previous Muslims' legacy. The Qur'an is the primary source of Islamic religious rules, which are the basis for determining the law. The Qur'an is believed to have originated from Allah. Its texts are considered sacred, so every Muslim must recognize it as the foundation of all kinds of Islamic superstructures. ${ }^{47}$ Sunnah is a cultural practice of life or a norm of behavior accepted communally by people who believe it includes all speech and behavior of the Prophet Muhammad. ${ }^{48}$ According to the term fiqh scholars, sunnah is the nature of law for actions required to do it in the form of indefinite demands in the sense that the person who does it and does not $\sin$ is the person who leaves it. ${ }^{49}$

Apart from Quran and Sunnah, figh siyasah dusturiyah comes from humans themselves and their environments. Political experts' views, 'urf, or customs the concerned community, local customs, past experiences, and rules have been made before. ${ }^{50}$ These sources can come from ijma (consensus), a joint decision to determine a good law for the people's benefit through

46 Ibid at 16.

47 Khalid Jindan \& Masrohin, Teori Politik Islam: Telaah Kritis Ibnu Taimiyah tentang Pemerintaban Islam (Surabaya: Risalah Gusti, 1995) at 51.

$48 \quad$ Ibid at 53.

49 Abdul Majid Asy-Syarafi, Ijtihad Kolektif(Jakarta: Pustaka Al-Kautsar, 2002) at 9.

50 Ahmad Sukardja \& Ahmad Sukardja, Piagam Madinab E Undang-Undang Dasar 1945 NRI 1945: Kajian Perbandingan tentang Dasar Hidup Bersama dalam Masyarakat yang Majemuk (Rawamangun, Jakarta: Sinar Grafika, 2012) at 11. 
deliberation, then using qiyas. Qiyas is a logical method to solve a problem related to a particular form of behavior's legality by establishing a positive or negative relationship between one form of behavior and another with a general principle. ${ }^{51}$

\section{B. Figh Siyasah Dusturiyah in Protecting Migrant Workers}

Work is one of the essential activities of human life. It becomes dominant compared to other activities, especially in fulfilling life necessities. Work can be defined as general or specific. In general, work includes all forms of effort made by humans, both in seeking material and non-material intellectual or physical, and matters relating to matters of life and the hereafter. ${ }^{52}$ Work is closely related to the workforce, including those who work for themselves and family members who do not receive payment in wages or those who are willing and able to work, which means that they are forced to be unemployed because they have no job opportunities. ${ }^{53}$ So labor is everyone willing and able to work. ${ }^{54}$ Article 1: 2 of the Workforce Law defines that labor as anyone capable of producing goods or services to fulfill his own needs and for the community.

The Qur'an also talks about employment. It refers to At-Taubah verse 105. Quraish Shihab, Indonesia's leading Quranic scholar, interprets the verse as follows, "Work, for the sake of Allah alone with various righteous and beneficial deeds, both for yourself and for the general public, then Allah will see that is to judge and reward your deeds." ${ }^{55}$ Thus, Islam encourages people to work and produce all kinds of work. It even makes it an obligation to those who are able. However, more than that, Allah will give a reward by his charity or work, as referred to An-Nahl verse 97.

51 Ibid at 56.

52 MB Hendri Anto, Pengantar Ekonomi Mikro Islam (Yogyakarta: Ekonisia UII, 2003) at 222.

53 Sonny Sumarsono, Ekonomi Manajemen Sumberdaya Manusia dan Ketenagakerjaan (Yogyakarta: Graha Ilmu, 2003) at 2.

54 Anto, supra note 52.

55 Moh Quraish Shihab, Tafsir al-Mishbāh: Pesan, Kesan, dan Keserasian al-Qur'an (Ciputat, Jakarta: Lentera Hati, 2005) at 670. 
In this regard, the right to get a job is guaranteed in the Indonesian State constitution. It is a human right for every citizen. Human rights are natural human rights. Once a human is born, that human right is attached to him as a human being. ${ }^{56}$ Under the aim of establishing benefits for all citizens, the government has several main tasks. First, the government creates laws and regulations under Islamic teachings, implements them, and defends laws and statutes.

Article 31 of Labor Law 13/2003 explains that workers' rights and opportunities to choose, get, or change jobs earn decent income at home or abroad. Indonesian citizens have the right to look for work in the country and go abroad. Not a few Indonesian citizens work abroad. The government does not remain silent by making various legal products so that the certainty and protection of Indonesian citizens working abroad can be protected. Also, Article 1:5 of Law 18/2017 determines the protection of migrant workers as all efforts to protect the interests of prospective and migrant workers, with their families as rights in all activities in legal, economic, and social aspects. In addition, Law 18/2017 aims that migrant workers must be protected from human trafficking, slavery and forced labor, victims of violence, abuse, crimes against human dignity, and other treatment that violates human rights based on Article 2 of Law 18/2017.

This provision conforms to the four principles of employment in Islam. First, human freedom. Islamic teachings are represented by the social piety activities of the Prophet Muhammad. He explicitly declared an anti-slavery attitude to build a tolerant and just society. Therefore, Islam does not tolerate slavery for any reason. Moreover, buying and selling workers and the neglect of rights -His rights do not respect human values, based on God's word in Surah As-Syua'ara verse 183, which prohibits harming human rights by doing damage. Article 2 of Law 18/2017 prohibits all forms of human trafficking. The definition of anti-trafficking in persons is that there is no recruitment, transportation, delivery, transfer, acceptance of the candidate of migrant workers with threats of violence, force, kidnapping, imprisonment, forgery, fraud, and abuse of power or a

56 Sri Warjiyati, "Instrumen Hukum Penegakan Hak Asasi Manusia" (2018) 15:1 Jurnal Justicia Islamica at 121. 
vulnerable position. Before, during, and after migrant workers' work, the process is also protected from all forms of entrapment of money, providing payments to obtain approval from the person who controls other people, whether carried out within the country or between countries in exploitation or resulting in exploitation. Law 18/2017 also accommodates equal rights in the regulation. The definition of equal rights is that candidates or migrant workers have equal rights, opportunities, and treatment to obtain decent work and livelihoods.

The second is the principle of human dignity. Islam places every human being, regardless of work and profession, in a noble and honorable position. Islam also really loves Muslims who are persistent in working for their lives. In Surah Al-Jumu'ah verse 10, God states to human beings scattered on the face of the earth to seek His bounty after performing prayers. This verse is strengthened by the hadith narrated by Imam Al-Baihaqi, "Not everyone of you eats a food better than from your sweat." It follows Article 2 of Law 18/2017 that recognizes human dignity and rights and the principle of non-discrimination. First, the principle of recognizing human dignity and rights is that the protection of migrant workers must reflect respect for human existence as God's creatures. One for the sake of honor and protection of human dignity. Second, the principle of nondiscrimination asserting their protection is carried out without any differentiation of treatment based on human differentiation based on religion, ethnicity, race, ethnicity, group, class, status. social, economic status, gender, language, and political beliefs.

The third is the principle of justice. Justice is vital for human life to create respect and proper rights by activities. Surah Al-Hadid verse 25 explains that God sent messengers with factual evidence. Thus, God would know who was helping His (religion) and His messengers, even though Allah did not see Him. Indeed, Allah is Mighty. Fair in this sense can be interpreted as fair in the administration of the means of living. Justice that must be upheld is the implementation of life-based on balance. The strong help the weak, the rich help the poor. On the other hand, the weak ones support justice positively, not by undermining the strong. The poor do not undermine the rich. Besides, justice in the workforce sector is also in 
obtaining production, distribution, and utilization. It is related to the transparency principle regulated in Article 2 of Law 18/2017 so that the protection of migrant workers carries out openly, clearly, and honestly.

Fourth, the principle of clarity of contract (agreement) and wage transactions. Islam is very concerned with the issue of the contract. Akad is one of the most important parts of economic life. Every believer is obliged to fulfill what has been promised, whether related to work, wages, or working time. A contract must practically regulate the relationship between workers and employers, including ethics, rights, and obligations between the two parties. This provision reflects in Al-Mukminun verse 8 .

The agreement also confirms administrative values and upholds moral values related to halal, legality, and ethics. Thus, openness in transactions is necessary to avoid speculative attitudes, fraud, collusion, corruption, and others in various economic activities. Islam forbids this because fraudulent practices will harm certain parties. Furthermore, wages or salaries are the right of economic fulfillment for workers who are obliged and should not be ignored by employers or employers. It is under God's word in Surah AlAhqaf (19), which states, "And for all are degrees according to what they did, that they may be paid back and they shall not be wronged."

The issue of workers' wages is critical. Islam guides employers to apply the principle of paying wages fairly and adequately. This principle is summarized in a hadith of the Prophet narrated by Imam Al-Baihaqi, "Give a salary to workers before dry his sweat, and tell him the terms of his salary, what he has been doing. ${ }^{57}$ Apart from that, as narrated by Imam Bukhori, Muslim, and Ahmad, "Rasulullah had his cupping, then he paid his wages to those who had them. ${ }^{58}$ The principle of clarity of the contracts and wage in Islamic law is protected for migrant workers before working. Then, Article 8 of Law 18/2017 covers two aspects, including administrative and technical. Protection of an administrative nature includes the completeness and validity of placement documents and

57 Afzal-ur-Rahman, Doktrin Ekonomi Islam (Kuala Lumpur: Dewan Bahasa \& Pustaka, 1994) at 248-252.

58 M Ali Hasan, Berbagai Macam Transaksi dalam Islam (Figh Muamalat) (Jakarta: RajaGrafindo Persada, 2003) at 161. 
determination of working conditions and conditions. The protection in technical aspects includes information dissemination, education, training, rights fulfillment facilities, and services in One-Stop Integrated Services (LTSA). Then, based on Article 19 of Law 18/2017, the pre-employment protection section regulates the contents of the work agreement, the term of the work agreement, the procedure for extension of the work agreement, and administrative sanctions for PPPMI. Therefore, they do not place migrant candidates, including the clarity of wages, in the work agreement.

\section{CONCLUSION}

The limited employment opportunities available in Indonesia have resulted in many Indonesian citizens working abroad. The risks faced by these migrant workers are the possibility of facing inhuman treatment, violations of law, human rights, and other rights. While the government protected migrant workers by issuing Law 18/2017, it has more specifically provided directions and objectives to protect migrant workers. It ensures human rights for migrant workers despite legal, economic, and social protection for them and their families. The protection of migrant workers viewed from fiqh siyasah dusturiyah is under the four principles of the workforce in Islam: human independence, human dignity, justice, and the clarity of the contract and wage transaction.

\section{ACKNOWLEDGMENTS}

None.

\section{COMPETING INTEREST}

The authors declared that they have no competing interests.

\section{REFERENCES}

Afzal-ur-Rahman, Doktrin Ekonomi Islam (Kuala Lumpur: Dewan Bahasa dan Pustaka, 1994). 
Anggriani, Riri, "Perlindungan Hukum bagi Irregular Migrant Workers Indonesia di Kawasan Asia Tenggara (Dalam Perspektif Hukum HAM Internasional)" (2017) 32:2 Yuridika 310-335.

Anto, MB Hendri, Pengantar Ekonomi Mikro Islam (Yogyakarta: Ekonisia UII, 2003).

Asy-Syarafi, Abdul Majid, Ijtihad Kolektif (Jakarta: Pustaka Al-Kautsar, 2002).

Atmaja, Hamdan Tri, "Model Pemberdayaan Keluarga Tenaga Kerja Wanita (TKW) Indonesia Berbasis Arena Produksi Kultural Dalam Upaya Menciptakan Keluarga Mandiri Sejabtera di Propinsi Jawa Timur" (2014) 41:1 Forum Ilmu Sosial Fakultas Ilmu Sosial Universitas Negeri Semarang.

Azra, Azyumardi, "Kesalehan dan Politik: Islam Indonesia" (2018) 25:3 Studia Islamika 639-650.

Bareta, Rizky Dian \& Budi Ispriyarso, "Politik Hukum Perlindungan Tenaga Kerja Indonesia Fase Purna Bekerja” (2018) 20:1 Kanun Jurnal Ilmu Hukum 163-182.

BNP2TKI, "Data Penempatan dan Perlindungan TKI Periode 1 Januari-31 Maret 2019" (2019) online: <http://portal.bnp2tki.go.id/uploads/data/ data_18-04-2019_010851_Laporan_Pengolahan_Data_BNP2TKI_ Bulan_Maret_.pdf>.

BP2MI, "Data Penempatan dan Perlindungan TKI Periode Tabun 2019" (2020) online: <https://bp2mi.go.id/uploads/statistik/images/data_21 -10-2020_Laporan_Pengolahan_Data_BNP2TKI_agustus_2020_(1) .pdf>.

BPS, Data Survei Angkatan Kerja Nasional (Badan Pusat Statistik Indonesia, 2017).

De La Vega, Connie \& Conchita Lozano-Batista, "21 Advocates Should Use Applicable International Standards to Address Violations of Undocumented Migrant Workers' Rights in the United States" in Anne F Bayefsky, Hum Rights Refug Internally Displac Pers Migr Work (Martinus Nijhoff Publishers, 2006) 517. 
Djazuli, H.A., Fiqh Siyasah Implementasi Kemaslahatan Umat dalam Rambu-Rambu Syari"ah (Jakarta: Kencana, 2003).

Era Moslem, "Pemerintah Hanya Jadikan TKI Sebagai Komoditas" (2020) online: <http://www.eramoslem.com/br/fo/48/12377,1v.html>

Hakim, Muhammad Lutfi, "Hermeneutik-Negosiasi dalam Studi FatwaFatwa Keagamaan: Analisis Kritik terhadap Pemikiran Khaled M. Abou El Fadl" (2020) 19:1 Istinbath 27-52.

Hardani, Ayuk \& Rahayu, "Politik Hukum Perlindungan Non-Derogable Rights Pekerja Migran Indonesia Tidak Berdokumen” (2019) 3:2 Refleksi Hukum: Jurnal Ilmu Hukum 115-128.

Hasan, M Ali, Berbagai Macam Transaksi dalam Islam (Figh Muamalat) (Jakarta: RajaGrafindo Persada, 2003).

Indonesian Ministry of Law and Human Rights, Laporan Akhir Analisis dan Evaluasi Hukum Mengenai Perlindungan Hak dan Keselamatan Pekerja Migran (Ministry of Law and Human Rights, 2016).

Iqbal, Muhammad, Fiqh Siyasah: Kontekstualisasi Doktrin Politik Islam (Jakarta: Gaya Media Pratama, 2001).

Jindan, Khalid \& Masrohin, Teori Politik Islam: Telaah Kritis Ibnu Taimiyah tentang Pemerintahan Islam (Surabaya: Risalah Gusti, 1995).

Lubis, Ali Akhbar Abaib Mas Rabbani, "Open Promotion Sekda Kabupaten Sambas: Perspektif Fikih Siyasah dan Perundang-Undangan di Indonesia" (2020) 1:2 Jornal of Islamic Law 158-181.

Manzhur, Ibn, Lisan al-Arab (Beirut: Dar al-Shadr, 1968).

Muhakki, Muhakki, "Mekanisme Suara Terbanyak Bagi Pemilu Legislatif (Studi Siyasah Dusturiyah)" (2011) 1:2 Al-Daulah: Jurnal Hukum dan Perundangan Islam 135-158.

Natalis, Aga \& Budi Ispriyarso, "Politik Hukum Perlindungan Pekerja Migran Perempuan di Indonesia” (2018) 13:2 Pandecta Research Law Journal 109-123. 
Prihatinah, Tri Lisiani, et al., "Kendala Perlindungan Hukum Terhadap Burub Migran di Kabupaten Cilacap” (2012) 12:2 Jurnal Dinamika Hukum.

Pulungan, J Suyuthi, Fiqh Siyasah: Ajaran, Sejarah dan Pemikiran (Jakarta: Raja Grafindo Persada, 1999).

Sani, Eprida \& Shary Charlotte Henriette Pattipeilohy, "Analisis Pengaruh Hukuman Mati Pekerja Migran Indonesia terhadap Hubungan Bilateral Indonesia dan Arab Saudi 2010-2018" (2020) 6:2 Journal of International Relations 238-247.

Shihab, Moh Quraish, Tafsir al-Misbbāb: Pesan, Kesan, dan Keserasian alQur'an (Ciputat, Jakarta: Lentera Hati, 2005).

Sukardja, Ahmad \& Ahmad Sukardja, Piagam Madinah \& UndangUndang Dasar 1945 NRI 1945: Kajian Perbandingan tentang Dasar Hidup Bersama dalam Masyarakat yang Majemuk (Jakarta: Sinar Grafika, 2012).

Sumarsono, Sonny, Ekonomi Manajemen Sumberdaya Manusia dan Ketenagakerjaan (Yogyakarta: Graha Ilmu, 2003).

Syariati, Ali, Imamah dan Umamah, Translated by Afif Muhammad (Mizan, 1989).

Taimiyah, Ibn, Siyasah al-Syar'iyah fi Ishlah al-Ra'I wa al-Ra'iyah (Mesir: Dar al-Kitab al-Arabi).

Tempo, "Depnakertrans Bantah RUU Perlindungan TKI Mengukubkan Trafficking” (2004) online: <https://www.tempointeraktif.com/hg/ nasional/2004/09/17/ brk,20040917-31,id.html>.

Tempo, "Komnas HAM, "Hak Asasi Burub Migran Indonesia" (2004) online: $<$ https://www.tempointeraktif.com/hg/narasi/2004/06/17/nrs,200406 17-07,id.html>.

Ullah, AKM Ahsan \& Sharifah Nurul Huda Alkaff, "Biological Remittance Among Migrant Workers: Social Ramifications in the Pbilippines and Indonesia" (2018) 53:6 Journal of Asian and African Studies 896-916. 
Ulum, Muhammad Bahrul, "Indonesian Democracy and Political Parties After Twenty Years of Reformation: A Contextual Analysis" (2020) 10:1 Indonesia Law Review.

Warjiyati, Sri, "Instrumen Hukum Penegakan Hak Asasi Manusia" (2018) 15:1 Jurnal Justicia Islamica.

Widaningrum, Ambar, "Public Trust and Regulatory Compliance" (2017) 21:1 Jurnal Ilmu Sosial dan Ilmu Politik 1.

Widiyahseno, Bambang, "Paradigma Baru Model Pelindungan Pekerja Migran Indonesia dalam Perspektif Undang-Undang RI Nomor 18 Tabun 2017" (2017) 4:3 Sosio Informa 501-513.

Wisnuwardhani, Savitri, Memahami Undang-Undang Perlindungan Pekerja Migran Indonesia: Kelebiban dan Kelemahan UU PPMI (Jakarta: Jaringan Buruh Migran: The Institute for Ecosoc Rights, 2018). 
174 | The Protection of Indonesian Migrant Workers under Figh Siyasah Dusturiyah

This page intentionally left blank 